\title{
Simultaneous Interpreter Booths: Not Always What You Expect Them to Be
}

\author{
Boris A. Naimushin* \\ New Bulgarian University \\ 21 Montevideo Str., Sofia, 1618, Bulgaria
}

Received 20.11.2014, received in revised form 22.12.2014, accepted 16.01.2015

\begin{abstract}
This article is aimed at stimulating discussion on pedagogical approaches to interpreter training. It examines certain exceptional situations where professional conference interpreters agree to perform simultaneous interpreting in substandard interpreter booths or other substandard working conditions of varying degrees, e.g. when working at governmental level. Interpretation courses, therefore, should allow time for discussions of such situations and of acceptable scenarios of work in substandard conditions, in order to prepare novice interpreters for real-life interpreting assignments where working conditions are non-negotiable and quitting is not an option to be considered.
\end{abstract}

Keywords: conference interpreting, simultaneous interpreting, interpreter booth, interpreter training, pedagogical approaches, substandard working conditions, governmental interpreter.

Research area: philology.

\section{Introduction}

Good working conditions are essential for the high quality of conference interpreting which is a very demanding and stressful profession (Herbert 1952:6, Kurz 2003 etc.). In recognition of this fact, ISO-standards have been established for booths and equipment. We expect the organizers to provide us with comfortable, sound-proofed and air-conditioned booths (fixed or mobile) with good light and comfortable chairs. We also really appreciate it when we can have a direct and complete view of all delegates.

Conference interpreting programs usually train students to work in such comfortable ISOlevel conditions. Unfortunately, simultaneous interpreter booths and equipment are not always what you expect them to be based on your university training. Sometimes even at high-level venues the working conditions fall far below the expected international standards. During my time in the profession of conference interpreting, I have experienced varying degrees of substandard working conditions under the circumstances that the AIIC Code of Professional Ethics describes as 'exceptional' (AIIC Code of Professional Ethics 2000, III, Article 7).

Before starting work for the Administration of the Bulgarian President in 2009, I would never have imagined that in certain circumstances orienteering may prove to be an essential skill for interpreters at governmental level. As is well known, orienteering is a family of sports that requires navigational skills using a map and compass to navigate from point to point

(c) Siberian Federal University. All rights reserved

* Corresponding author E-mail address: bnaimushin@nbu.bg 
in diverse and usually unfamiliar terrain, and normally moving at speed (Wikipedia 2014). The only thing I usually do not need is a compass and the other thing I usually do not have is an orientation map. All the other essential features of the discipline are more often than not firmly in place. The terrain is usually diverse and very unfamiliar, and I have to navigate from point to point at high speed.

\section{Underground Interpreters in an Archeological Site}

On 2 September 2011, the Heads of State of South-East European countries met at the Roman archaeological site of Viminacium (Serbia) for the 9th Summit of South East European countries headlined Contemporary Art and Reconciliation in South-East Europe. Dating back to the 1st century AD, Viminacium was a provincial capital and military camp of the Roman province of Moesia, and the capital of Moesia Superior. Today it is an archaeological site occupying a total of 1,100 acres and contains remains of temples, streets, squares, amphitheatres, palaces, hippodromes and Roman baths.

The Summit was hosted by the President of Serbia and attended by the Presidents of Albania, Bosnia and Herzegovina, Bulgaria, Croatia, FYROM Macedonia and Montenegro as well as by high-level representatives such as Irina Bokova (Director-General of UNESCO), Androulla Vassiliou (European Commissioner for Education, Culture, Multilingualism, Youth and Sport) and Gabriella Battami-Dragoni (Director General of the Council of Europe for Education, Culture and Heritage, Youth and Sports).

My duties on this trip were to provide consecutive and simultaneous interpretation services for the President of Bulgaria Georgi Parvanov. We flew to Beograd early in the morning and then were transferred by cars and busses to the archaeological site of Viminacium located about $100 \mathrm{~km}$ east of the Serbian capital. Although the average driving time to the site is $1 \mathrm{hr} 47 \mathrm{~min}$ by bus and $1 \mathrm{hr} 16 \mathrm{~min}$ by $\operatorname{taxi}^{1}$, the presidential motorcades escorted by Serbian traffic police covered the distance in less than $40 \mathrm{~min}$. The first plenary session at the Viminacium Information Centre was scheduled for $10.30 \mathrm{am}$.

We arrived at the site at about 10.15 am and the participants were offered refreshments in a small hall where they had the opportunity to engage in informal conversations. Luckily for me, President Parvanov told me my services were not needed during this informal session so I could focus on my existential problem, i.e. finding my booth. This is almost always a problem during such short and intensive events when you are supposed to rush to your booth the moment you arrive, sit down and start interpreting. It's relatively easy when the booths are in the same hall where the event is held but Viminacium was certainly not one of those easy cases.

In such situations interpreters usually are expected to take care of themselves and take their professional reputation into your own hand. You arrive at the site of the event and it is you duty to find your booth and be there with your headphones and your mike on when your President needs your services. When a dozen of Presidents arrive at the same time and the meeting is due to start in about 15 minutes, the protocol people are busy taking care of Heads of State, not their humble interpreters. In other words, you have to be confident, self-assertive and pushy in a positive sense. If you fail to identify the right person to ask for directions and instructions, chances are you will fail to show up in your booth on time for the show.

Due to lack of space in the Viminacium Information Centre where the meeting was held the booths (four in a row) were located in the hallway of the floor beneath the hall (Ground 
-1), right next to the staircase leading to the Royal Roman Mausoleum. A big screen was placed in front of the booths to make up for the inconvenience although visibility of the screen differed from booth to booth. Working from screens on Ground -1 without a direct view of the speaker and the room is not a very pleasant experience but it was just one of those 'exceptional circumstances' where any attempt at discussing professional standards would not have been particularly welcomed. Anyway, in such situations you usually have no time to bring up the issue, let alone figure out whom to bring the issue up with.

Another problem was posed by the 'systematic use of relay', one more arrangement to be avoided as much as possible under the AIIC Code of Professional Ethics. Each President brought his own interpreter to interpret their interventions from their national languages into English and vice versa. On several occasions during the first two sessions I found myself in a state of heightened stress when the speakers made references to some of the UNESCO World Heritage List sites in their countries or names of their distinguished national artists. Their interpreters equipped with the written copies of the statements of their Presidents would deliver the names of the sites at machine-gun speed leaving the rest of us with the pulse rate way outside the normal range, to say the least. Here are a few examples (Dialogue among Civilizations 2012:14, 15, 23, 26):

One of the most important issues is the status of Serbian spiritual and cultural heritage in Kosovo, notably medieval monuments which are classified on UNESCO endangered list: the monastery of Visoki Decani, Patriarchate of Pec, Monastery of Gracanica and the church of Ljeviska Mother of God... Besides the monasteries in Kosovo I have already mentioned, there are also Stari Ras, Sopocani, monastery of Studenica and Gamzigrad - Felix Romulian.

Boris Tadić,

President of the Republic of Serbia

In Albanian literature, the best model is Ismail Kadare, but also in other arts such as painting, ballet, cinematography, music, there are Albanian names like Ibrahim Kodra, Angjelin Prelocaj, James Belushi, Inva Mula, Eliza Dushku, Saimir Pirgu, Ardian Paci, Artan Shabani, Klejdi Kadiu and many more who have confirmed themselves as an authentic part of the mosaic of values of world contemporary art.

Bamir Topi,

President of the Republic of Albania

Bosnia and Herzegovina is especially proud of the two sites which were inscribed on UNESCO World Heritage List - The Old Bridge of Mostar - inscribed in 2005, and The Mehmed Paša Sokolović Bridge of Višegrad inscribed in 2007... Many cultural and historical monuments of the first order were not spared from destruction including true architectural gems such as The Old Bridge of Mostar, Ferhadija mosque in Banja Luka, Aladža mosque in Foca, Orthodox Church in Mostar, Sarajevo City Hall ...

Bakir Izetbegović, Chairman of the Presidency of Bosnia and Herzegovina

After the meeting the interpreters had the opportunity to go down two flights of stairs leading to the Royal Roman Mausoleum and enjoy a glass of wine contemplating the collection of frescoes containing late antique masterpieces. It was a nice and relaxing end to this rather stressful day of underground interpreting from screen at 
the lovely archaeological site of Viminacium, Serbia.

\section{An Orienteering Exercise in the Kremlin Corridors}

On February 4-6, 2009, the Bulgarian President Georgi Parvanov came to visit Moscow on a state visit for the official launch of the Year of Bulgaria in Russia. After a tête-à-tête meeting between the two State Heads in the Green Hall of the Great Kremlin Palace, Presidents Parvanov and Medvedev joined the plenary talks in the Saint Catherine Hall.

Having done consecutive Bulgarian-Russian interpreting during the tête-à-tête meeting, I followed the Presidents to the Saint Catherine Hall. As the Presidents were entering the hall, I dived into a small side door on the left as instructed the previous day plunging into a breathtaking adventure of navigating to my booth in an unfamiliar terrain of narrow side corridors and spiral stairs moving at highest possible speed. The booth, I was told, was located on the next floor. I was expected to find the booth and be in full combat gear before the start of the plenary session.

It has always remained a mystery to me but I really made it into the booth in time for the session, a little breathless from running down the corridors and climbing up the stairs, only to find out that the booth was a one-person cubbyhole with no direct view of the plenary hall and no screen to work from. I also had absolutely no contact with my Bulgarian colleague in the next cubbyhole who was supposed to interpret from Russian into Bulgarian as the two booths were separated by a solid wall.

When the plenary meeting was declared closed and I heard chairs being moved in the hall, I ripped the headphones off my ears and repeated the navigation exercise in the reverse order running up the corridors and dashing down the stair. A little more breathless than after the first exercise, I popped out of the side door the moment the two State Heads were emerging from the plenary hall.

\section{A Booth as Big as a Hall}

In May 2013 I experienced yet another extreme in terms of booth sizes. This time it was the roomiest booth you could have imagined but again with no direct view of the audience and no screens. The scene the 2nd World Forum on Intercultural Dialogue held on May 29 -June 1, 2013 in Baku, Azerbaijan.

Following the official opening ceremony at the Heydar Aliyev Center, the first Plenary Session "Cultural Corridors in Southeast Europe, Black Sea and Caucasus Regions - Shared Heritage, Common Responsibilities, Sustainable Future" took place at the JW Marriott Absheron Baku Hotel. The panel of speakers featured Mr. Georgi Parvanov, President of the Republic of Bulgaria (2002-2012), Mr. Stjepan Mesić, President of Croatia (2000 - 2010), Ms. Irina Bokova, DirectorGeneral of UNESCO, Mr. Elmar Mammadyarov, Minister of Foreign Affairs of the Republic of Azerbaijan, Ms. Kolinda Grabar-Kitarović, Assistant to the Secretary General for Public Diplomacy, NATO etc.

Regular simultaneous interpreting was provided from/into Russian, Azerbaijani, English, French, Spanish and Arabic. Regular interpreters worked in regular movable booths in the back of the hall. My colleague from Croatia and I were asked well in advance to be prepared to interpret the interventions of Presidents Parvanov and Mesić acting as pivots from Bulgarian and Croatian into Russian. I even received a personal email from the organisers a week before the event reminding me of this arrangement.

The opening ceremony finished at 12.00 , the plenary session was scheduled for 15.00. So we went back to the hotel, had lunch and 
were taking advantage of the wonderful sunny weather having coffee on the terrace of the hotel. Normally, simultaneous interpreters do not have the responsibility to check whether the booths are in place and the equipment is in order. You just come in on time, i.e. at least $30 \mathrm{~min}$ before the beginning of the event, sit down in your booth, make sure there is enough water at hand, arrange the available materials, chat with the colleagues etc. However, when you accompany a delegation and are their only interpreter, things are a bit different. You are not a regular interpreter hired for the entire event and by definition provided with a workplace. As a rule, you need an additional booth because otherwise you will disrupt the arrangement of language combinations in the booths. This is especially when all interpreters are required to do retour interpreting which is a common practice in Eastern Europe, Russia and Asia. For instance, if I sat in the Russian-English booth and interpreted from Bulgarian into Russian, there would be no English interpretation of the speech. If, in the same booth, I chose to interpret from Bulgarian into English, there would be no Russian interpretation.

This could only work in situations when all interpreters work exclusively into their Languages A and we have a Russian booth, an English booth etc. On several occasions, e.g. in UNESCO in Paris or at the OSCE Summit in Astana, Kazakhstan (2010) I have interpreted the interventions of President Parvanov from Bulgarian into English in the English booth acting as a pivot for the other booths. However, in Baku this simply would not work.
So I decided to go down to the hall and check up on the preparations for the session. I was not even very much surprised to find out that no booth had been envisaged for me and my colleague. The technicians had no idea about this arrangement. Luckily, they had an extra console, so after some deliberations and consultations and some pressure on my behalf, the console was installed on a chair in the adjacent hall. As a result, we ended up working in the roomiest booth we had ever worked in - in fact, the whole adjacent hall was turned into a lovely spacious booth! Unfortunately, with no view of the audience and no screens. Still, the speeches of the two Presidents were safely interpreted and reached the ears of all the participants.

\section{Conclusion}

The aim of this article is to stimulate discussion on pedagogical approaches to interpreter training. As we have seen, there are certain exceptional situations where professional conference interpreters agree to perform simultaneous interpreting in substandard interpreter booths or other substandard working conditions of varying degrees, e.g. when working at governmental level.

Interpretation courses, therefore, should allow time for discussions of such situations and of acceptable scenarios of work in substandard conditions aimed at preparing novice interpreters for real-life interpreting assignments where working conditions are non-negotiable and quitting is not an option to be considered.

\footnotetext{
http://www.rome2rio.com/s/Belgrade/Viminacium (accessed 10 November 2014)
}

\section{References}

1. AIIC Code of Professional Ethics (2000), Available at: http://aiic.net/page/54/code-ofprofessional-ethics/lang/1 (accessed 10 November 2014). 
2. Dialogue among Civilizations. Summit of the Heads of State of South-East Europe Contemporary Art and Reconciliation in South-East Europe. Republic of Serbia, 1-2 September 2011. United Nations Educational, Scientific and Cultural Organization (2012), Available at: http://unesdoc. unesco.org/images/0021/002164/216440e.pdf (accessed 10 November 2014).

3. Herbert J. The Interpreter's Handbook: How to Become a Conference Interpreter. Genève, Librairie de l'Université, 1952. 73 p.

4. Kurz, Ingrid. "Physiological Stress During Simultaneous Interpreting: A Comparison of Experts and Novices", in The Interpreters' Newsletter, Number 12, E.U.T., 2003, p. 51-67.

5. Orienteering. Wikipedia (2014), Available at: http://en.wikipedia.org/wiki/Orienteering (accessed 10 November 2014).

\title{
Будка переводчика-синхрониста: \\ ожидания не всегда оправдываются
}

\author{
Б.А. Наймушин \\ Новый болгарский университет \\ Болгария, 1618, София, ул. Монтевидео, 21
}

Обсуждаются исключительные ситуачии, когда профессиональные конферени-переводчики согламаются работать в нестандартных будках или при других ненормальных условиях труда ниже установленного стандарта, что иногда наблюдается, как ни странно, при работе на правительственном уровне. Отмечается, что при обучении конференипереводчиков необходимо уделять время рассмотрению и обсуждению подобных ситуаиий, что позволит полнее подготовить начинающих спечиалистов к работе в реальных условиях, когда нет возможности обсуждать предложенные условия труда и также нет возможности отказаться от выполнения своих обязанностей.

Ключевые слова: конференц-перевод, синхронный перевод, будка переводчика, подготовка переводчика, педагогические подходы, ненормальные условия труда, правительственный переводчик.

Научная специальность: 10.00.00 - филологические науки. 